\title{
Widening use of dexamethasone implant for the treatment of macular edema
}

This article was published in the following Dove Press journal:

Drug Design, Development and Therapy

16 August 2017

Number of times this article has been viewed

\section{Vincenza Bonfiglio \\ Michele Reibaldi \\ Matteo Fallico \\ Andrea Russo \\ Alessandra Pizzo \\ Stefano Fichera \\ Carlo Rapisarda \\ lacopo Macchi \\ Teresio Avitabile \\ Antonio Longo}

Department of Ophthalmology, University of Catania, Catania, Italy

Correspondence: Vincenza Bonfiglio Department of Ophthalmology,

University of Catania, Via S Sofia 76,

95100, Catania, Italy

Tel +39095 378 I29 I

Fax +39095 378 I 288

Email enzabonfiglio@gmail.com

\begin{abstract}
Sustained-release intravitreal $0.7 \mathrm{mg}$ dexamethasone (DEX) implant is approved in Europe for the treatment of macular edema related to diabetic retinopathy, branch retinal vein occlusion, central retinal vein occlusion, and non-infectious uveitis. The implant is formulated in a biodegradable copolymer to release the active ingredient within the vitreous chamber for up to 6 months after an intravitreal injection, allowing a prolonged interval of efficacy between injections with a good safety profile. Various other ocular pathologies with inflammatory etiopathogeneses associated with macular edema have been treated by DEX implant, including neovascular age-related macular degeneration, Irvine-Gass syndrome, vasoproliferative retinal tumors, retinal telangiectasia, Coats' disease, radiation maculopathy, retinitis pigmentosa, and macular edema secondary to scleral buckling and pars plana vitrectomy. We undertook a review to provide a comprehensive collection of all of the diseases that benefit from the use of the sustained-release DEX implant, alone or in combination with concomitant therapies. A MEDLINE search revealed lack of randomized controlled trials related to these indications. Therefore we included and analyzed all available studies (retrospective and prospective, comparative and non-comparative, randomized and nonrandomized, single center and multicenter, and case report). There are reports in the literature of the use of DEX implant across a range of macular edema-related pathologies, with their clinical experience supporting the use of DEX implant on a case-by-case basis with the aim of improving patient outcomes in many macular pathologies. As many of the reported macular pathologies are difficult to treat, a new treatment option that has a beneficial influence on the clinical course of the disease may be useful in clinical practice.
\end{abstract}

Keywords: macular edema, dexamethasone, intravitreal, implant, corticosteroids

\section{Introduction}

The sustained-release intravitreal (IV) $0.7 \mathrm{mg}$ dexamethasone (DEX) implant (Ozurdex $^{\circledR}$, Allergan Pharmaceuticals, Irvine, CA, USA) is approved in Europe for the treatment of macular edema related to the following diseases: diabetic retinopathy, branch retinal vein occlusion or central retinal vein occlusion, and noninfectious uveitis. ${ }^{1}$

DEX is one of the 3 most commonly used intraocular corticosteroids together with triamcinolone acetonide (TA) and fluocinolone acetonide. However, compared with these, DEX differs in its pharmacokinetics and pharmacodynamics properties due to certain biological effectiveness: different glucocorticoid receptor binding affinity (DEX $>$ fluocinolone $>$ triamcinolone) and different anti-inflammatory activities (DEX $=$ fluocinolone and is 5 times more active than triamcinolone). ${ }^{1,2}$ The advantage of a DEX implant, containing micronized, preservative-free DEX $0.7 \mathrm{mg}$ in a biodegradable copolymer of polylactic-co-glycolic acid (which eventually breaks down 
into carbon dioxide and water), is the release of the active ingredient within the vitreous chamber for up to 6 months after an IV injection. All these aforementioned features allow reduction in the frequency of injections with benefit in terms of hospital and patient resource saving, including diminished complications related to injection procedure (eg, retinal detachment, endophthalmitis, lens iatrogenic injury, etc). However, in real life it has been shown that a shorterinterval re-treatment is required because of the loss of the drug's effectiveness before 6 months, with a reported range varying from 4 to 5.9 months., ${ }^{3,4}$ Another relevant pharmacological aspect, as demonstrated by experimental studies, is the reduction of IV drugs half-life in vitrectomized eyes compared with non-vitrectomized ones, making their use ineffective. ${ }^{5}$ On the contrary, DEX implant has the advantage of maintaining the same half-life and, therefore, the same pharmacological properties in both vitrectomized and nonvitrectomized eyes. ${ }^{6-8}$

Regarding complications related to the use of DEX implant, pivotal studies and real-life studies have confirmed a good safety profile with only a few complications: cataract progression in the range from $29.8 \%{ }^{9}$ to $67.9 \%,{ }^{10}$ closely related to the number of implants received, and an increase of intraocular pressure (IOP) $>10 \mathrm{mmHg}$ from baseline reported in a range of $15.4 \%{ }^{9}$ and $27.7 \%{ }^{10}$ of cases. There are several reviews collecting literature data about the approved use of sustained-release DEX implants. However, there are various ocular pathologies with inflammatory etiopathogeneses associated with macular edema, such as: neovascular agerelated macular degeneration (nAMD); Irvine-Gass syndrome (IGS); vasoproliferative retinal tumors (VPRTs); retinal telangiectasia and Coats' disease; radiation maculopathy; retinitis pigmentosa; macular edema secondary to scleral buckling and pars plana vitrectomy (PPV), all of which have been treated by DEX implant.

The aim of this review was to provide a systematic collection of all of the diseases that benefit from the use of the sustained-release DEX implant alone or in combination with concomitant therapies in order to provide a valuable therapy option for these diseases in clinical practice.

\section{Methods}

MEDLINE databases for the period 2009 to September 2016 were searched by using the medical subject heading "Dexamethasone intravitreal implant/Ozurdex" and the keywords "macular edema, age-related macular degeneration, Irvine-Gass, pseudophakic cystoid macular edema, post-operative macular edema, PPV, scleral buckling, retinitis pigmentosa, prostaglandin, radiation macular edema, telangiectasia." Studies were limited to the English language. Because randomized controlled trials on these topics were lacking, all studies (retrospective and prospective, comparative and non-comparative, randomized and nonrandomized, single center and multicenter, and case reports) were analyzed. Aims, and anatomical and functional outcomes, and complications after DEX implant were analyzed.

\section{nAMD}

Approved first-line therapy for nAMD is based on the use of anti-vascular endothelial grow factor (VEGF) IV injections such as pegaptanib, ranibizumab, and aflibercept. However, there are patients who have a non-complete response to anti-VEGF injections as well as patients who, after an optimal functional and anatomical response, develop tachyphylaxis. ${ }^{11}$ The explanation for this incomplete response lies in the multifactorial pathogenesis of AMD, which involves VEGF, inflammation, and oxidative stress, as seen in histological studies performed on neovascular membranes after their surgical excision. Neovascular membrane growth in the subretinal space is stimulated by activated macrophages (and other inflammatory cells secreting cytokines) and enzymes that can damage the Bruch's membrane. ${ }^{12}$ Therefore, inflammation is another potential target of nAMD treatment that could be counteracted by the use of corticosteroids.

Combination therapy consisting of anti-VEGF therapy and a corticosteroid relies on the use of drugs with different mechanisms of action, and could allow the reduction of anti-VEGF IV injection frequency and therefore, improve long-term efficacy and safety while reducing scarring results. ${ }^{13-16}$ Using combination therapies to treat nAMD dates back to photodynamic therapy (PDT), when it was associated with the IV TA injection. ${ }^{17,18}$ However, side effects due to IV TA, such as cataract progression and increased IOP, sometimes resistant to medical therapy, halted these procedures despite anatomical and functional benefits. ${ }^{19}$ Cataract surgery has been reported in around $45.2 \%$ of eyes that underwent triamcinolone injection, ${ }^{19}$ and ocular hypertension (IOP $>21 \mathrm{mmHg}$ ) in around $44.6 \%$ of eyes, with IOP-lowering surgery required in $0.3 \%$ of eyes. ${ }^{20}$

The LuceDex study ${ }^{21}$ was the first study using the IV DEX injections ( $500 \mathrm{mg}$ in $0.05 \mathrm{~mL}$ ), followed by IV ranibizumab (4 monthly injections of $0.5 \mathrm{mg}$ in $0.05 \mathrm{~mL}$ ) that was compared with IV ranibizumab monotherapy (Group 2; total 
37 patients). After 4 consecutive months, in both groups, ranibizumab pro re nata treatment was administered if signs of lesion activity were present. The results of this study showed a clear benefit for combination therapy, with reduction in the dimension of the choroidal neovascular membrane, detected by fluorescein angiography, improvement in visual acuity, and reduced treatment frequency. Central macular thickness (CMT) and volume reductions were also observed, although these changes were not statistically significant.

After the approval of the DEX implant, several authors evaluated its efficacy in nAMD ${ }^{22-25}$ (Table 1). Compared with ranibizumab monotherapy, studies showed no long-term improvement of best corrected visual acuity (BCVA) and reduction of CMT; ${ }^{22-25}$ however, DEX implant in some cases allowed a reduced number of anti-VEGF injections. ${ }^{23,24}$

One study ${ }^{24}$ reported an incidence of cataract surgery of $9 \%$ in ranibizumab-treated eyes and $33 \%$ in eyes receiving 2 DEX implants. The incidence of ocular hypertension ranged from $15 \%$ to $42 \%,{ }^{22-25}$ all treated with topical hypotonizing therapy.

\section{IGS}

The most likely physiopathological hypothesis for IGS is an inflammatory response instigated by the inflammatory mediators released during and after surgical procedures, causing alterations to the blood-retinal barrier. Many risk factors have been identified, such as posterior capsule rupture and vitreous loss, as well as the use of iris retractors, the presence of an epiretinal membrane, a vein occlusion, a history of uveitis or diabetes and the use of prostaglandin eye drops. ${ }^{26}$

First-line treatment for IGS involves the use of different therapies: topical nonsteroidal anti-inflammatory drugs (NSAIDs), oral acetazolamide, and topical corticosteroids. In patients resistant to such treatments, the following offlabel treatment options have been tried: ${ }^{26-32}$

- IV anti-VEGF

- Subcutaneous interferon $\alpha 2$ a injections

- IV infliximab (anti-tumor necrosis factor- $\alpha$ )

- Intra-, retro-, and peribulbar corticosteroids

- PPV

Several authors have evaluated the efficacy of DEX implant for chronic IGS ${ }^{33-45}$ (Table 2).

Most of the studies had a 6-month follow-up; they showed a significant improvement in BCVA and a significant reduction in CMT with 1 DEX implant. Two prospective studies $^{38,43}$ of DEX compared with IVTA showed similar functional effects and anatomical effects: one found a lower incidence of ocular hypertension in the DEX group (at 6 months $0 \%$ vs $20 \%, P=0.044$ ).

A retrospective long-term study ${ }^{44}$ that included 58 cases of IGS in a total of 100 eyes found that efficacy was maintained at 24 months, after a mean number of 1.77 DEX implants in the first year and 1.70 in the second year. At 24 months, an IOP $>25 \mathrm{mmHg}$ was found in $6.2 \%$ of the patients, all treated with hypotensive eye drops and not requiring filtering surgery. ${ }^{44}$

\section{VPRTs}

Several approaches have been used to treat VPRTs, including cryotherapy, laser photocoagulation, PDT, IV anti-VEGF, plaque brachytherapy, and PPV. ${ }^{45-47}$

VPRTs treated by DEX and PDT were reported in 3 cases $^{48}$ (Table 3). Total involution of the tumor was reported within 2 months and regression of exudates continued for several months, leaving fibrotic scar tissue in the inferior half of the retina. ${ }^{48}$

\section{Retinal telangiectasia and Coats' disease Retinal telangiectasia}

Yannuzzi et $\mathrm{al}^{49}$ have recently classified different forms of idiopathic macular telangiectasia: aneurismal telangiectasia, idiopathic perifoveal telangiectasia, and occlusive telangiectasia. Although several approaches have been suggested for the treatment of idiopathic macular telangiectasia (including laser photocoagulation, ${ }^{50}$ PDT, ${ }^{51}$ IV antiVEGF, ${ }^{52} \mathrm{PPV}^{53}$ ), no treatment has yet been shown to provide a consistent effect on visual acuity. Also, corticosteroids have been used to treat these vascular pathologies due to their biological effect ${ }^{54}$ and DEX implant can be assumed to be an useful therapeutic device, ${ }^{55,56}$ which can also be administered in pediatric patients ${ }^{57}$ (Table 4).

In these cases, with a longer follow-up, multiple DEX implants were performed, at each time successfully (leading to BCVA improvement and CMT reduction). ${ }^{56-58}$

\section{Coats' disease}

In Coats' disease, ablative therapy by laser photocoagulation and cryotherapy is the gold standard of treatment ${ }^{57}$ with photocoagulation preferred over cryotherapy in cases with little or no subretinal fluid..$^{57}$ IV therapies such as anti-VEGF and steroids could be used to improve anatomic and visual outcomes, ${ }^{58,59}$ in particular, in combination with ablative therapies. IV corticosteroids, including DEX implant ${ }^{60-62}$ 


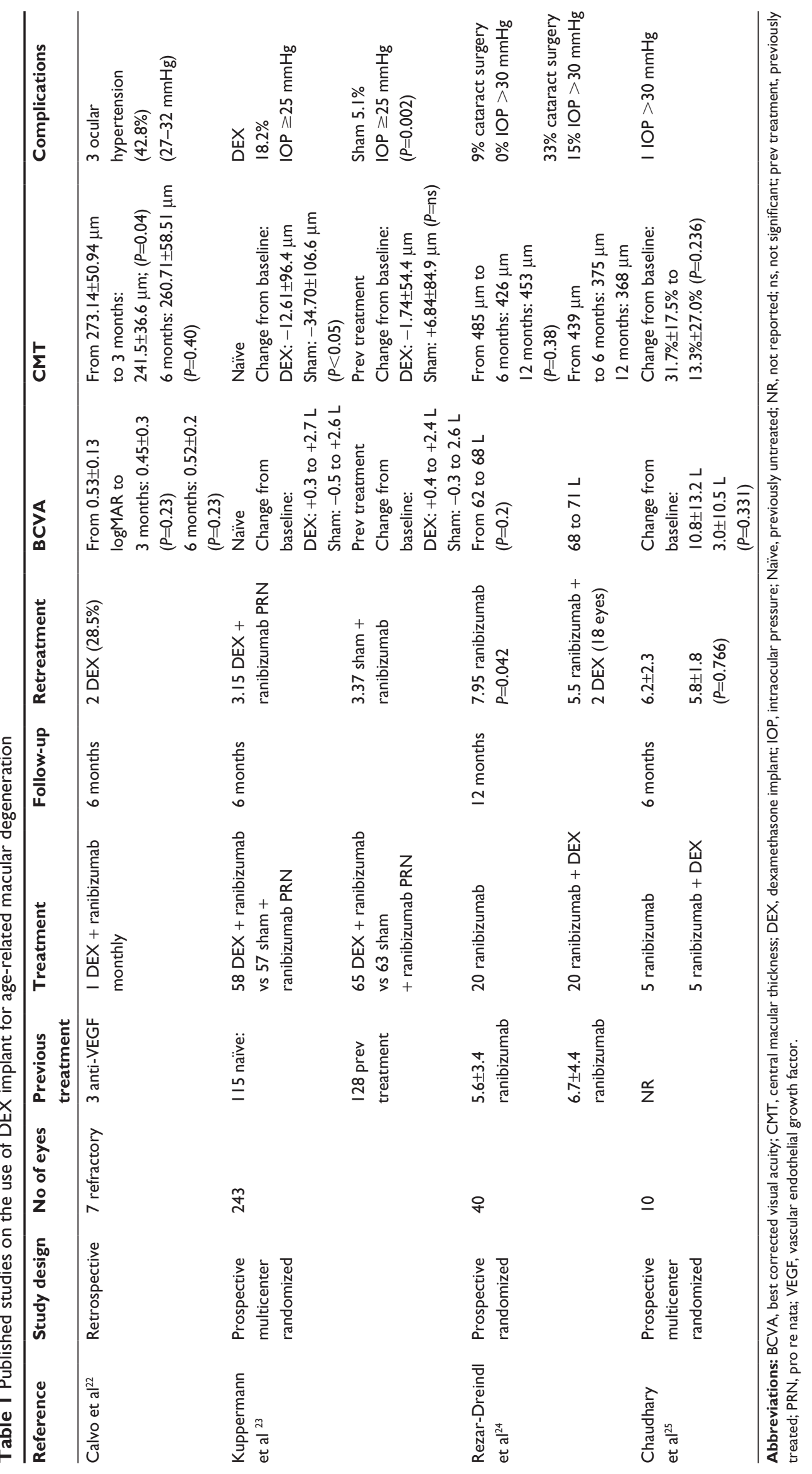




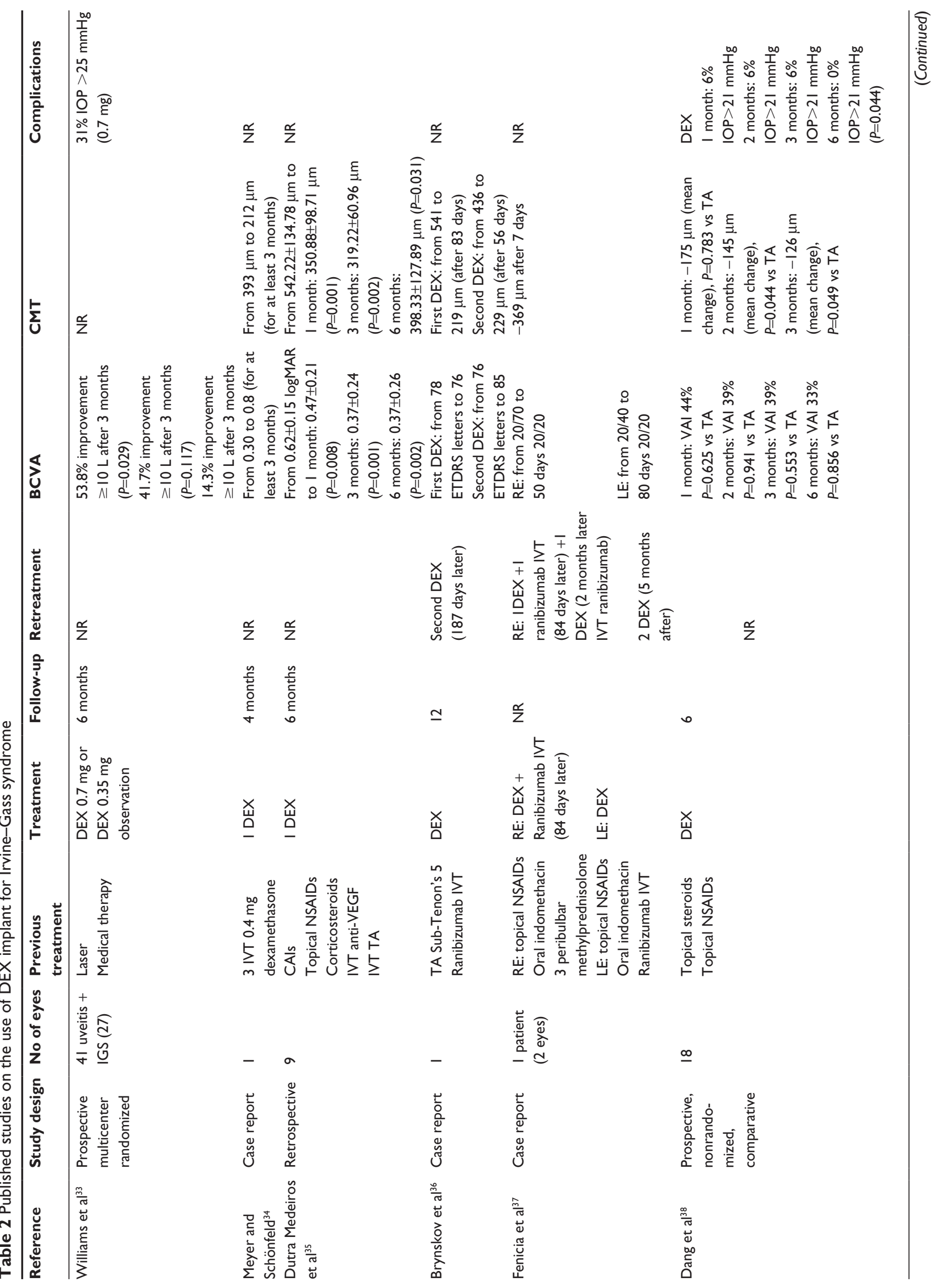




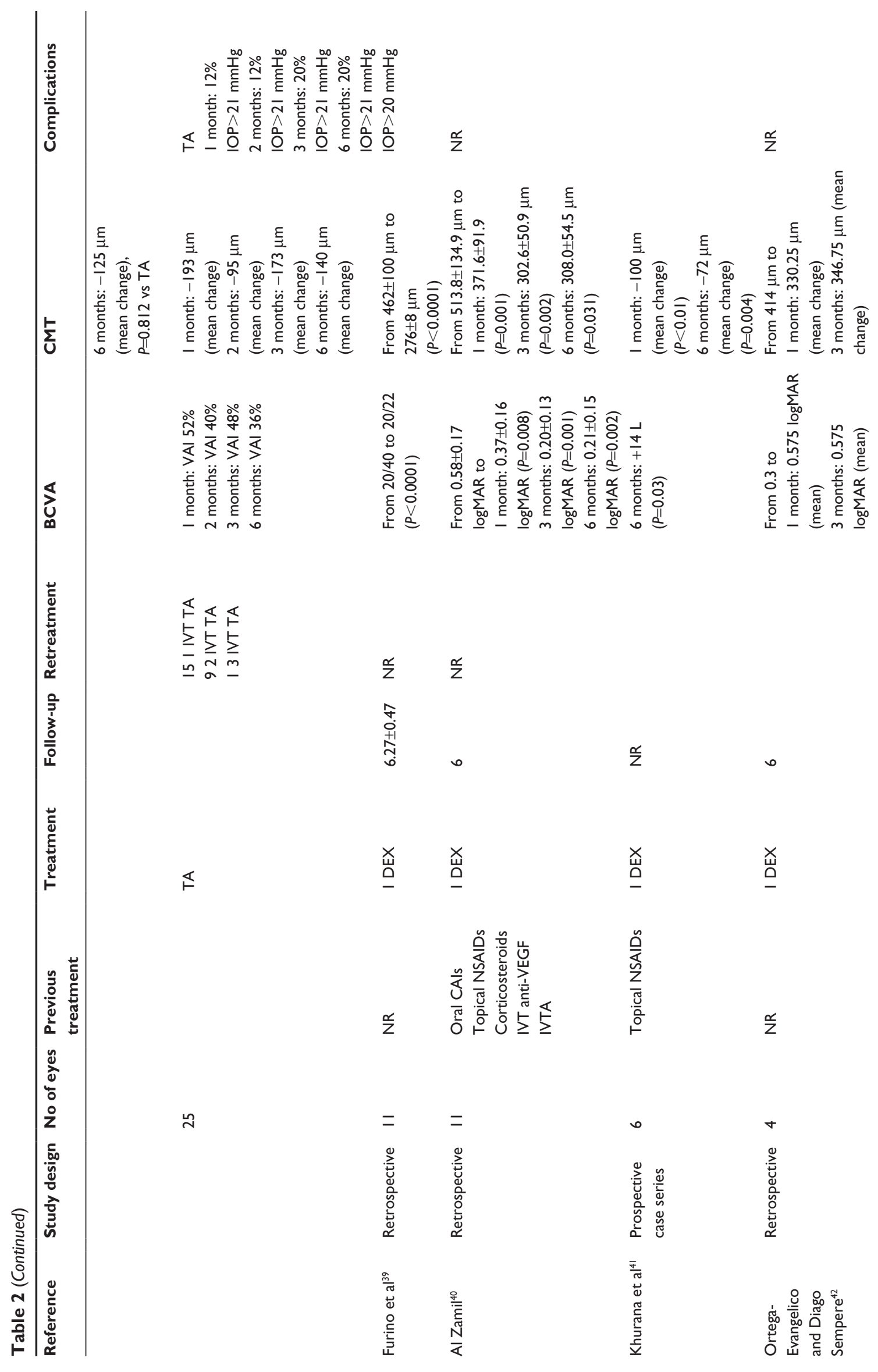




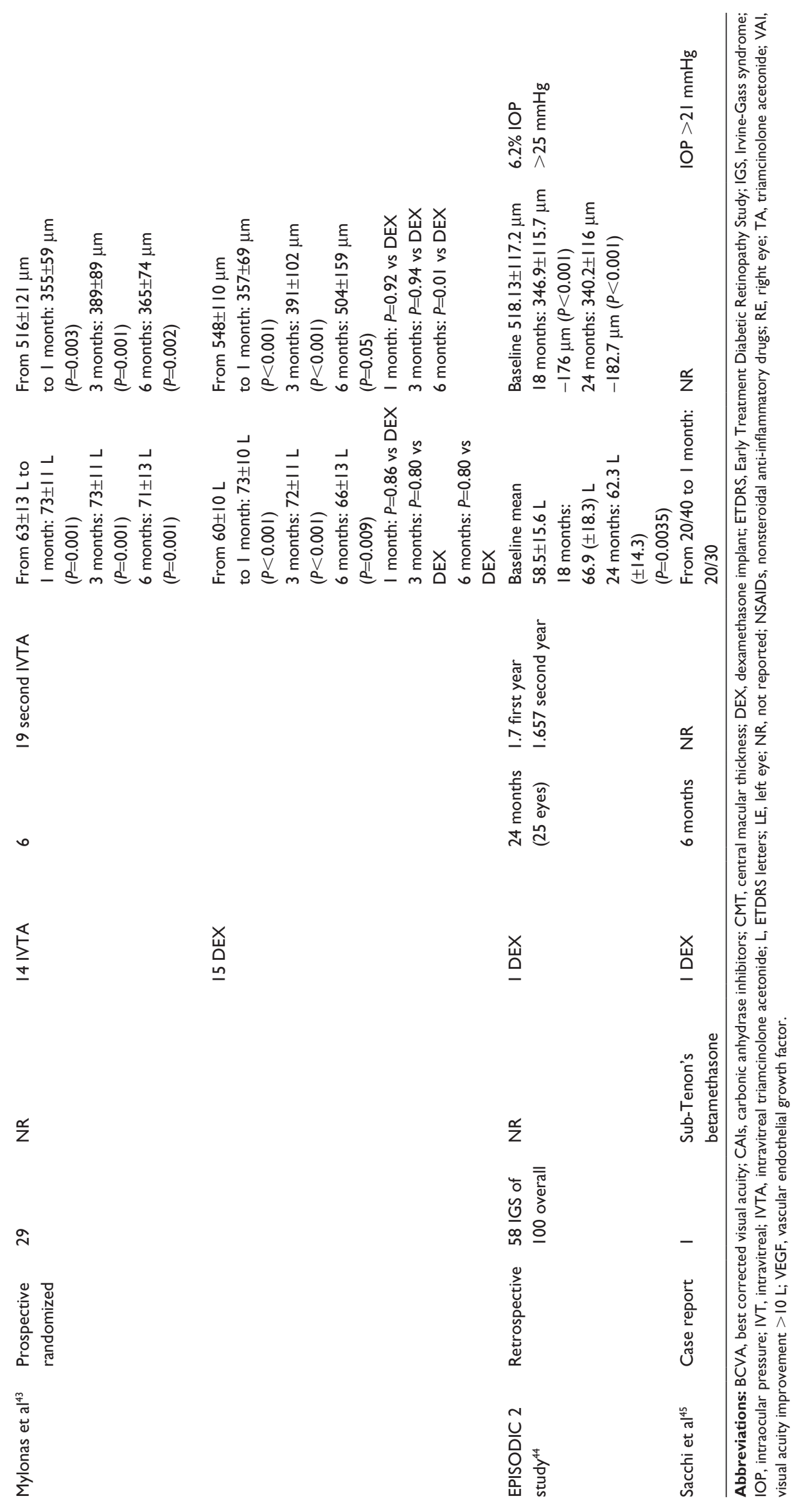


Table 3 DEX in vasoproliferative retinal tumors

\begin{tabular}{|c|c|c|c|c|c|c|c|c|c|}
\hline Reference & $\begin{array}{l}\text { Study } \\
\text { design }\end{array}$ & $\begin{array}{l}\text { No of } \\
\text { eyes }\end{array}$ & Previous treatment & Treatment & Follow-up & Retreatment & BCVA & CMT & Complications \\
\hline Cebeci et al ${ }^{48}$ & Case report & 3 & $\begin{array}{l}\text { IVT BEV } \\
\text { Laser photocoagulation }\end{array}$ & DEX & 12 months & $\begin{array}{l}\text { I DEX + PDT } \\
\text { (I week after) }\end{array}$ & $\begin{array}{l}\text { From } 20 / 25 \\
\text { to } 20 / 40\end{array}$ & NR & $\begin{array}{l}\text { I subcapsular } \\
\text { cataract }\end{array}$ \\
\hline
\end{tabular}

Abbreviations: BCVA, best corrected visual acuity; BEV, bevacizumab; CMT, central macular thickness; DEX, dexamethasone implant; IVT, intravitreal; NR, not reported; PDT, photodynamic therapy.

have been used to reduce intraocular inflammation, tighten capillary walls, and suppress cell proliferation, also having anti-VEGF properties, ${ }^{58}$ (Table 5).

In one case, DEX implant led to a resolution of the exudative retinal detachment allowing laser photocoagulation of telangiectatic vessels. ${ }^{63}$ In other cases, final BCVA was influenced by subfoveal fibrosis, present at the time of the treatment ${ }^{58}$ or existing over a long-term. ${ }^{60}$

\section{Radiation maculopathy}

Several treatments have been proposed for radiation maculopathy, including laser photocoagulation, PDT, periocular injection of TA, IV anti-VEGF and, most recently, DEX implant (Table 6) ${ }^{63-68}$ All of these studies demonstrated a significant anatomical benefit with DEX implant in cases of recalcitrant radiation macular edema, with significant changes in visual acuity in most of the cases. Two comparative studies ${ }^{65,67}$ comparing DEX implant with anti-VEGF therapy, found no difference in outcomes, and a reduction in the number of injections in DEX-treated eyes. ${ }^{65}$

IOP increased in some eyes, ${ }^{63,64,66}$ all successfully treated by topical hypotonizing therapy. Cataract development in these cases ${ }^{64-66}$ could be caused by DEX or the radiation therapy.

\section{Retinitis pigmentosa}

The exact pathogenesis of macular edema, whether it is related to chronic and low-grade inflammatory process ${ }^{69}$ or to autoimmune process as antiretinal antibodies ${ }^{70}$ or to the failure of the retinal pigment epithelium pumping mechanism, is unknown as yet. ${ }^{71}$ Treatments attempted include topical and systemic administration of CAI, ${ }^{71}$ NSAIDs, retinal laser photocoagulation, vitrectomy surgery, ${ }^{72}$ and IV anti-VEGF. ${ }^{73}$ Also, IV corticosteroids injections have been performed as these drugs may modulate the inflammatory mediators and the autoimmune process. ${ }^{74-76}$

The studies reporting on the use of DEX in macular edema related to retinitis pigmentosa consist of case report studies, which include only a few eyes (Table 7). ${ }^{77-80} \mathrm{Nev-}$ ertheless, an anatomical and functional improvement has been shown, but a relapse of macular edema occurred before 6 months from the implant ${ }^{77}$ and an additional DEX was required in some cases. ${ }^{77,78}$ DEX implant proved to be safe with an IOP rise $>21 \mathrm{mmHg}$ recorded in only one eye. ${ }^{78}$

Table 4 Published studies on the use of DEX implant for retinal telangiectasia

\begin{tabular}{|c|c|c|c|c|c|c|c|c|c|}
\hline Reference & $\begin{array}{l}\text { Study } \\
\text { design }\end{array}$ & $\begin{array}{l}\text { No of } \\
\text { eyes }\end{array}$ & $\begin{array}{l}\text { Previous } \\
\text { treatment }\end{array}$ & Treatment & Follow-up & Retreatment & BCVA & CMT & Complications \\
\hline $\begin{array}{l}\text { Sandali } \\
\text { et al }{ }^{55}\end{array}$ & Case report & I & 3 BEV IVT & DEX & 15 months & $2 \mathrm{DEX}$ & $\begin{array}{l}\text { From } 20 / 32 \text { to } \\
\text { I month: } 20 / 20\end{array}$ & $\begin{array}{l}\text { From } 398 \mu \mathrm{m} \\
\text { to I month: } \\
250 \mu \mathrm{m}\end{array}$ & NR \\
\hline $\begin{array}{l}\text { Loutfi } \\
\text { et } \mathrm{al}^{56}\end{array}$ & Case report & 1 & $\begin{array}{l}3 \text { BEV IVT } \\
\text { I IVTA }\end{array}$ & DEX & NR & $3 \mathrm{DEX}$ & $\begin{array}{l}\text { From } 0.3 \text { to } 0.59 \\
\text { logMAR: } 6 \text { weeks } \\
\text { after Ist DEX; } \\
\text { from } 0.3 \text { to } 0.64 \\
\text { logMAR: } 6 \text { weeks } \\
\text { after } 2 \text { nd DEX; } \\
\text { from } 0.3 \text { to } 0.78 \\
\text { logMAR: } 2 \text { weeks } \\
\text { after } 3 \text { rd DEX }\end{array}$ & $\begin{array}{l}\text { From } 397 \mu \mathrm{m} \\
\text { to } 286 \mu \mathrm{m} \text { : } \\
6 \text { weeks after } \\
\text { I }^{\circ} \mathrm{DEX} \text {; } \\
6 \text { weeks after } \\
2^{\circ} \mathrm{DEX} \text { : } \\
279 \mu \mathrm{m} \text {; } \\
2 \text { weeks after } \\
3^{\circ} \mathrm{DEX} \text { : } \\
279 \mu \mathrm{m}\end{array}$ & NR \\
\hline $\begin{array}{l}\text { Lei and } \\
\text { Lam }^{62}\end{array}$ & Retrospective & 1 & $\begin{array}{l}8 \text { ranibizumab } \\
\text { IVT + laser }\end{array}$ & DEX & 17 months & $4 \mathrm{DEX}$ & $\begin{array}{l}\text { From I to } 52 \text { weeks: } \\
0.5 \text { logMAR }\end{array}$ & $\begin{array}{l}\text { From } 607 \mu \mathrm{m} \\
\text { to } 52 \text { weeks: } \\
346 \mu \mathrm{m}\end{array}$ & NR \\
\hline
\end{tabular}

Abbreviations: BCVA, best corrected visual acuity; BEV, bevacizumab; CMT, central macular thickness; DEX, dexamethasone implant; IVT, intravitreal; IVTA, intravitreal triamcinolone acetonide; NR, not reported. 

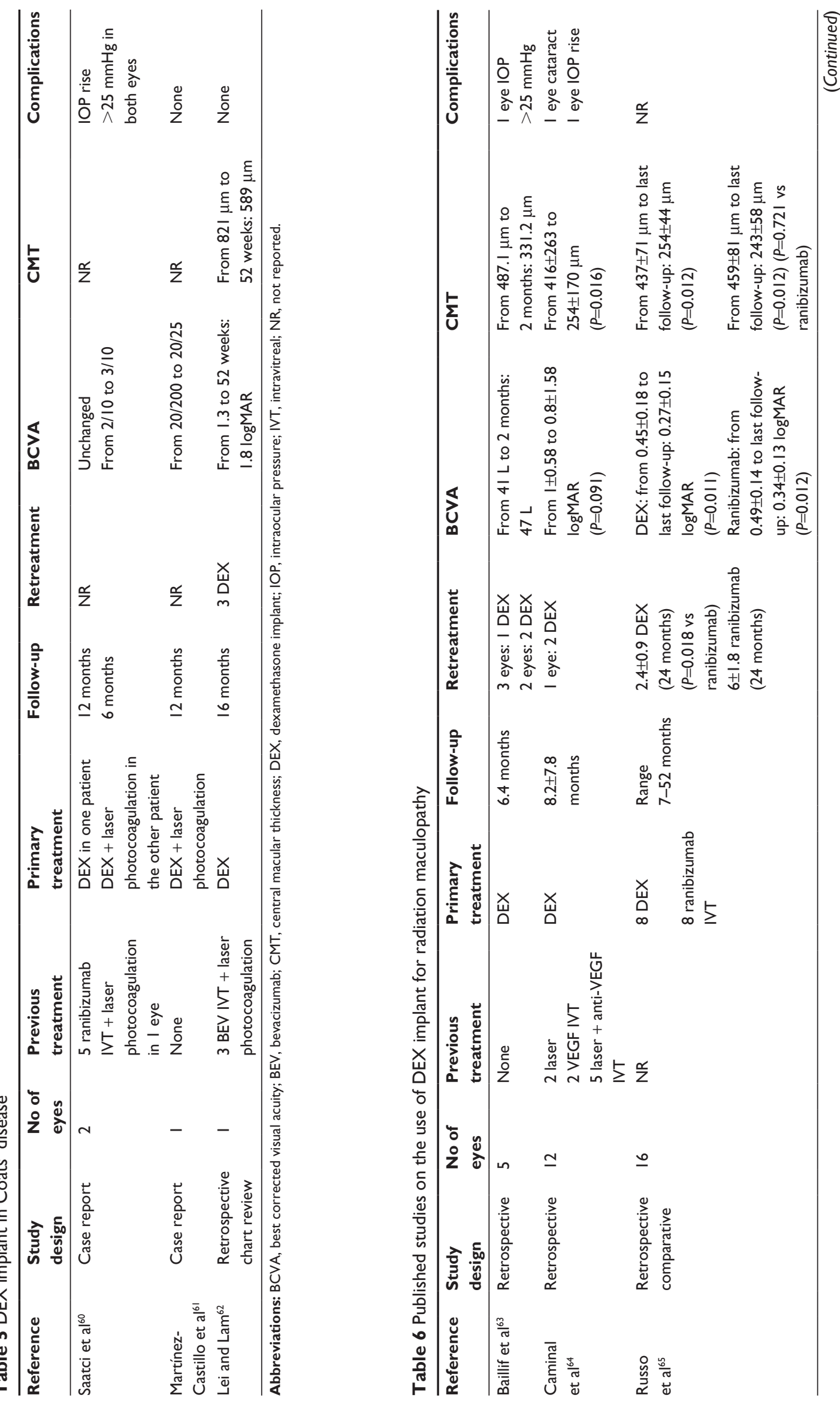


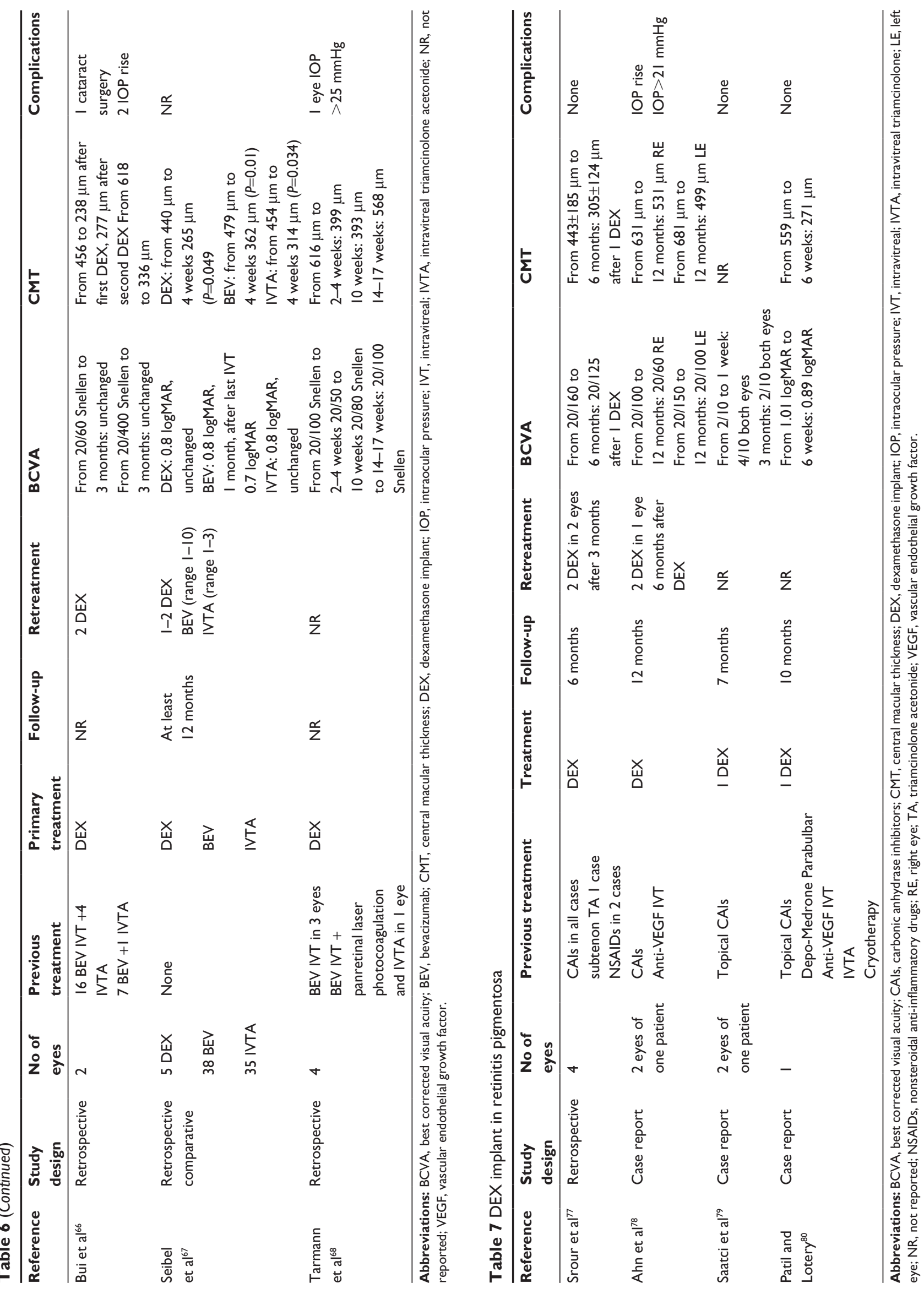




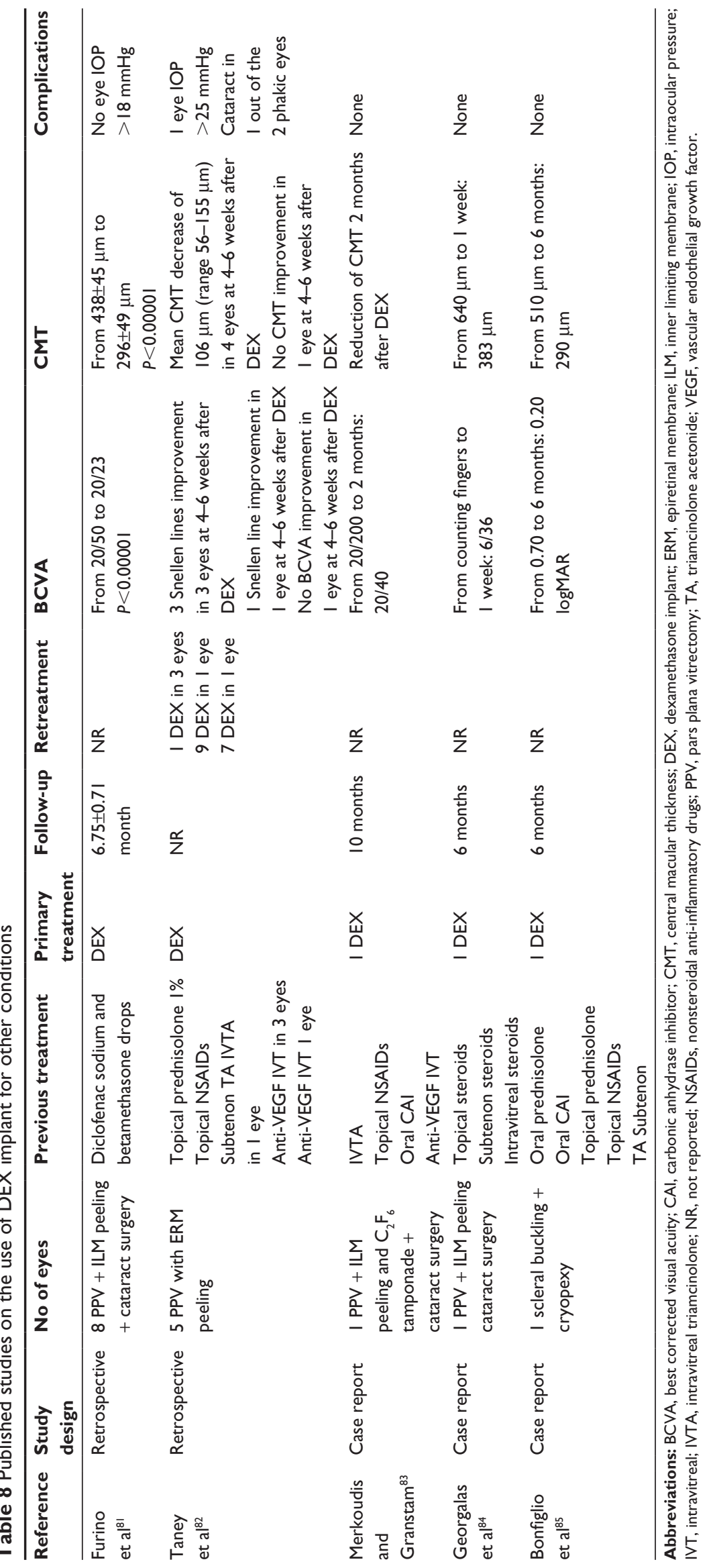




\section{DEX implant in macular edema after retinal surgery}

DEX implant was used also in case of macular edema secondary to PPV for epiretinal membrane or macular hole or scleral buckling (Table 8). ${ }^{81-85}$ In all cases, an anatomical and functional improvement was shown, even though in 2 cases, multiple DEX implants were performed because of recurrent macular edema. ${ }^{82}$ Additionally, the use of DEX allowed resolution of severe choroidal inflammation detected in 1 case following scleral buckle surgery. ${ }^{85}$

\section{Conclusion}

The use of DEX implant for all of the aforementioned macular pathologies merits consideration, and the results reported can support the use of DEX implant on a case-bycase basis with the aim of improving patient outcomes in many macular pathologies.

In many of these cases, DEX implant allowed a reduction of CMT with an improvement of BCVA, even if, at long term, many eyes required retreatment because DEX implant started to lose its efficacy, sometimes at 3 months after the injection.

Many of these cases were refractory to previous treatments, and DEX implant was administered as the last treatment option. Consequently, the functional results provided may be influenced by the lateness of DEX implant use. Therefore, considering that many of the reported macular pathologies may be difficult to treat and that some of them are not especially uncommon, having an awareness of a new treatment option and its influence on the clinical course of the disease may represent a great assistance in clinical practice. Furthermore, the use of DEX remains the only solution in treating macular edema in vitrectomized eyes where the efficacy of other IV drug injections, such as anti-VEGF, is lost due to their pharmacokinetic properties.

DEX implant-related adverse events in this expandinguse scenario are consistent with those previously documented for the DEX treatment of diabetic macular edema, uveitis, and retinal vein occlusion. ${ }^{10,86,87}$ In the cases that we analyzed, cataract was reported in up to $33 \%$ of the eyes after 2 DEX implants, ${ }^{24}$ and the occurrence of ocular hypertension (IOP $\geq 25 \mathrm{mmHg}$ ) from $6 \%{ }^{38}$ to $31 \%,{ }^{32}$ all treated with topical therapy.

In conclusion, DEX implant may allow less frequent anti-VEGF treatment ${ }^{24,65}$ and therefore, the advantages for the patient are clear: the need to undergo stressful treatment is removed while ocular and systemic adverse effects are reduced.

\section{Acknowledgments}

We thank Ray Hill, an independent medical writer, who provided English-language editing and journal styling before submission on behalf of Health Publishing \& Services Srl. Technical editing and publication fees for this manuscript were supported by Allergan.

\section{Author contributions}

All authors contributed to developing the concepts, design, and/or analysis and interpretation of data in this review, writing/revising the manuscript, and approved the final version before submission and agreed to be accountable for all aspects of the work.

\section{Disclosure}

The authors report no conflicts of interest in this work.

\section{References}

1. Dugel PU, Bandello F, Loewenstein A. Dexamethasone intravitreal implant in the treatment of diabetic macular edema. Clin Ophthalmol. 2015;9:1321-1335.

2. Yang Y, Bailey C, Loewenstein A, Massin P. Intravitreal corticosteroids in diabetic macular edema: pharmacokinetic considerations. Retina. 2015;35(12):2440-2449.

3. Bezatis A, Spital G, Höhn F, et al. Functional and anatomical results after a single intravitreal Ozurdex injection in retinal vein occlusion: a 6-month follow-up - the SOLO study. Acta Ophthalmol. 2013;91(5): e340-e347.

4. Coscas G, Augustin A, Bandello F, et al. Retreatment with Ozurdex for macular edema secondary to retinal vein occlusion. Eur J Ophthalmol. 2014;24(1):1-9.

5. Chin HS, Park TS, Moon YS, Oh JH. Difference in clearance of intravitreal triamcinolone acetonide between vitrectomized and non vitrectomized eyes. Retina. 2005;25(5):556-560.

6. Chang-Lin JE, Burke JA, Peng Q. Pharmacokinetics of a sustained release dexamethasone intravitreal implant in vitrectomized and non vitrectomized eyes. Invest Ophthalmol Vis Sci. 2011;52(7):4605-4609.

7. Shaikh AH, Petersen MR, Sisk RA, Foster RE, Riemann CD, Miller DM. Comparative effectiveness of the dexamethasone intravitreal implant in vitrectomized and non-vitrectomized eyes with macular edema secondary to central retinal vein occlusion. Ophthalmic Surg Lasers Imaging Retina. 2013;44(1):28-33.

8. Adan A, Pelegrín L, Rey A, et al. Dexamethasone intravitreal implant for treatment of uveitic persistent cystoid macular edema in vitrectomized patients. Retina. 2013;33(7):1435-1440.

9. Haller JA, Bandello F, Belfort R Jr, et al; Ozurdex GENEVA Study Group. Dexamethasone intravitreal implant in patients with macular edema related to branch or central retinal vein occlusion twelve-month study results. Ophthalmology. 2011;118(12):2453-2460.

10. Boyer DS, Yoon YH, Belfort R Jr, et al; Ozurdex MEAD Study Group. Three-year, randomized, sham-controlled trial of dexamethasone intravitreal implant in patients with diabetic macular edema. Ophthalmology. 2014;121(10):1904-1914.

11. Rosenfeld PJ, Brown DM, Heier JS, et al; MARINA Study Group. Ranibizumab for neovascular age-related macular degeneration. N Engl J Med. 2006;355(14):1419-1431.

12. Ding X, Patel M, Chan CC. Molecular pathology of age-related macular degeneration. Prog Retin Eye Res. 2009;28(1):1-18.

13. Spaide RF. Rationale for combination therapy in age-related macular degeneration. Retina. 2009;29(Suppl 6):S5-S7. 
14. Adamis AP. The rationale for drug combinations in age-related macular degeneration. Retina. 2009;29(Suppl 6):S42-S44.

15. Couch SM, Bakri SJ. Review of combination therapies for neovascular age-related macular degeneration. Semin Ophthalmol. 2011; 26(3):114-120.

16. Das RA, Romano A, Chiosi F, et al. Combined treatment modalities for age related macular degeneration. Curr Drug Targets. 2011;12(2): 182-189.

17. Kvanta A, Algvere PV, Berglin L, et al. Subfoveal fibrovascular membranes in age-related macular degeneration express vascular endothelial growth factor. Invest Ophthalmol Vis Sci. 1996;37(9):1929-1934.

18. Gallego-Pinazo R, Marín-Lambíes C, Marín-Olmos F, et al. Intravitreal dexamethasone as an enhancer for the anti-VEGF treatment in neovascular ARMD: recovering an old ally. Arch Soc Esp Oftalmol. 2010; 85(2):79-80.

19. Thompson JT. Cataract formation and other complications of intravitreal triamcinolone for macular edema. Am J Ophthalmol. 2006; 141(4):629-637.

20. Roth DB, Verma V, Realini T, Prenner JL, Feuer WJ, Fechtner RD. Long-term incidence and timing of intraocular hypertension after intravitreal triamcinolone acetonide injection. Ophthalmology. 2009;116(3): 455-460.

21. Ranchod TM, Ray SK, Daniels SA, Leong CJ, Ting TD, Verne AZ. LuceDex: a prospective study comparing ranibizumab plus dexamethasone combination therapy versus ranibizumab monotherapy for neovascular age-related macular degeneration. Retina. 2013;33(8):1600-1604.

22. Calvo P, Ferreras A, Al Adel F, Wang Y, Brent MH. Dexamethasone intravitreal as adjunct therapy for patients with wet age-related macular degeneration with incomplete response to ranibizumab. $\mathrm{Br} J$ Ophthalmol. 2015;99(6):723-726.

23. Kuppermann BD, Goldstein M, Maturi RK, et al; Ozurdex ${ }^{\circledR}$ ERIE Study Group. Dexamethasone intravitreal implant as adjunctive therapy to ranibizumab in neovascular age-related macular degeneration: a multicenter randomized controlled trial. Ophthalmologica. 2015;234(1):40-54.

24. Rezar-Dreindl S, Eibenberger K, Buehl W, et al. Role of additional dexamethasone for the management of persistent or recurrent neovascular age-related macular degeneration under ranibizumab treatment. Retina. 2017;37(5):962-970.

25. Chaudhary V, Barbosa J, Lam WC, et al. Ozurdex in age-related macular degeneration as adjunct to ranibizumab (The OARA Study). Can $J$ Ophthalmol. 2016;51(4):302-305.

26. Shelsta HN, Jampol LM. Pharmacologic therapy of pseudophakic cystoid macular edema: 2010 update. Retina. 2011;31(1):4-12.

27. Sivaprasad S, Bunce C, Wormland R. Non-steroidal anti-inflammatory agents for cystoid macular edema following cataract surgery: a systematic review. Br J Ophthalmol. 2005;89(11):1420-1422.

28. Catier A, Tadayoni R, Massin P, Gaudric A. Advantages of acetazolamide associated with anti-inflammatory medications in postoperative treatment of macular edema. J Fr Ophtalmol. 2005;28(10): 1027-1031.

29. Spitzer MS, Ziemssen F, Yoeruek E, Petermeier K, Aisenbrey S, Szurman P. Efficacy of intravitreal bevacizumab in treating postoperative pseudophakic cystoid macular edema. J Cataract Refract Surg. 2008;34(1):70-75.

30. Deuter CM, Gelisken F, Stübiger N, Zierhut M, Doycheva D. Successful treatment of chronic pseudophakic macular edema (Irvine-Gass syndrome) with interferon alpha: a report of three cases. Ocul Immunol Inflamm. 2011;19(3):216-218.

31. Wu L, Arevalo JF, Hernandez-Bogantes E, Roca JA. Intravitreal infliximab for refractory pseudophakic cystoid macular edema: results of the Pan-American Collaborative Retina Study Group. Int Ophthalmol. 2012;32(3):235-243.

32. Thach AB, Dugel PU, Flindall RJ. A comparison of retrobulbar versus sub-Tenon's corticosteroid therapy for cystoid macular edema refractory to topical medications. Ophthalmology. 1997;104(12): 2003-2008.
33. Williams GA, Haller JA, Kuppermann BD, et al; Dexamethasone DDS Phase II Study Group. Dexamethasone posterior-segment drug delivery system in the treatment of macular edema resulting from uveitis or Irvine-Gass syndrome. Am J Ophthalmol. 2009;147(6):1048-1054.

34. Meyer LM, Schönfeld CL. Cystoid macular edema after complicated cataract surgery resolved by an intravitreal dexamethasone $0.7-\mathrm{mg}$ implant. Case Rep Ophthalmol. 2011;2(3):319-322.

35. Dutra Medeiros M, Navarro R, Garcia-Arumí J, Mateo C, Corcóstegui B. Dexamethasone intravitreal implant for treatment of patients with recalcitrant macular edema resulting from Irvine-Gass syndrome. Invest Ophthalmol Vis Sci. 2013;54(5):3320-3324.

36. Brynskov T, Laugesen CS, Halborg J, Kemp H, Sørensen TL. Longstanding refractory pseudophakic cystoid macular edema resolved using intravitreal $0.7 \mathrm{mg}$ dexamethasone implants. Clin Ophthalmol. 2013;7:1171-1174.

37. Fenicia V, Balestrieri M, Perdicchi A, MauriziEnrici M, DelleFave M, Recupero SM. Intravitreal injection of dexamethasone implant and ranibizumab in cystoid macular edema in the course of Irvine-Gass syndrome. Case Rep Ophthalmol. 2014;5(2):243-248.

38. Dang Y, Mu Y, Li L, et al. Comparison of dexamethasone intravitreal implant and intravitreal triamcinolone acetonide for the treatment of pseudophakic cystoid macular edema in diabetic patients. Drug Des Devel Ther. 2014;8:1441-1449.

39. Furino C, Boscia F, Recchimurzo N, Sborgia C, Alessio G. Intravitreal dexamethasone implant for macular edema following uncomplicated phacoemulsification. Eur J Ophthalmol. 2014;24(3):387-391.

40. Al Zamil WM. Short-term safety and efficacy of intravitreal $0.7-\mathrm{mg}$ dexamethasone implants for pseudophakic cystoid macular edema. Saudi J Ophthalmol. 2015;29(2):130-134.

41. Khurana RN, Palmer JD, Porco TC, Wieland MR. Dexamethasone intravitreal implant for pseudophakic cystoid macular edema in patients with diabetes. Ophthalmic Surg Lasers Imaging Retina. 2015; 46(1):56-61.

42. Ortega-Evangelio L, Diago Sempere T. Study of the effect of intravitreal dexamethasone implant in pseudophakic macular edema. Preliminary. Arch Soc Esp Oftalmol. 2015;90(7):303-307.

43. Mylonas G, Georgopoulos M, Malamos P, et al; Macula Study Group Vienna. Comparison of dexamethasone intravitreal implant with conventional triamcinolone in patients with postoperative cystoid macular edema. Curr Eye Res. 2016;9:1-5.

44. Bellocq D, Pierre-Kahn V, Matonti F, et al. Effectiveness and safety of dexamethasone implants for postsurgical macular oedema including Irvine-Gass syndrome: the EPISODIC-2 study. Br J Ophthalmol. 2017;101:333-341.

45. Sacchi M, Villani E, Gilardoni F, Nucci P. Efficacy of intravitreal dexamethasone implant for prostaglandin-induced refractory pseudophakic cystoid macular edema: case report and review of the literature. Clin Ophthalmol. 2014;8:1253-1257.

46. Turell ME, Singh AD. Vascular tumors of the retina and choroid: diagnosis and treatment. Middle East Afr J Ophthalmol. 2010;17(3): 191-200.

47. Yeh S, Wilson DJ. Pars plana vitrectomy and endoresection of a retinal vasoproliferative tumor. Arch Ophthalmol. 2010;128(9):1196-1199.

48. Cebeci Z, Oray M, Tuncer S, Tugal Tutkun I, Kir N. Intravitreal dexamethasone implant (Ozurdex) and photodynamic therapy for vasoproliferative retinal tumours. Can J Ophthalmol. 2014;49(4): e83-e84.

49. Yannuzzi LAI, Bardal AM, Freund KB, Chen KJ, Eandi CM, Blodi B. Idiopathic macular telangiectasia. Arch Ophthalmol. 2006;124(4): 450-460.

50. Park DW, Schatz H, McDonald HR, Johnson RN. Grid laser photocoagulation for macular edema in bilateral juxtafoveal telangiectasis. Ophthalmology. 1997;104(11):1838-1846.

51. De Lahitte GD, Cohen SY, Gaudric A. Lack of apparent short-term benefit of photodynamic therapy in bilateral, acquired, parafoveal telangiectasis without subretinal neovascularization. Am J Ophthalmol. 2004;138(5):892-894. 
52. Takayama KI, Ooto S, Tamura H, et al. Intravitreal bevacizumab for type 1 idiopathic macular telangiectasia. Eye. 2010;24(9):1492-1497.

53. Terauchi G, Matsumoto CS, Shinoda K, et al. Pars plana vitrectomy combined with focal endolaser photocoagulation for idiopathic macular telangiectasia. Case Rep Med. 2014;2014:786578.

54. Wu L, Evans T, Arévalo JF, et al. Long-term effect of intravitreal triamcinolone in the nonproliferative stage of type II idiopathic parafoveal telangiectasia. Retina. 2008;28(2):314-319.

55. Sandali O, Akesbi J, Rodallec T, Laroche L, Nordmann JP. Dexamethasone implant for the treatment of edema related to idiopathic macular telangiectasia. Can J Ophthalmol. 2013;48(4):e78-e80.

56. Loutfi M, Papathomas T, Kamal A. Macular oedema related to idiopathic macular telangiectasia type 1 treated with dexamethasone intravitreal implant (ozurdex). Case Rep Ophthalmol Med. 2014;2014:231913.

57. Sigler EJ, Randolph JC, Calzada JI, Wilson MW, Haik BG. Current management of Coats disease. Surv Ophthalmol. 2014;59(1):30-46.

58. Ghazi NG, Al Shamsi H, Larsson J, Abboud E. Intravitreal triamcinolone in Coats' disease. Ophthalmology. 2012;119(3):648-649.

59. Chaudhary KM, Mititelu M, Lieberman RM. An evidence-based review of vascular endothelial growth factor inhibition in pediatric retinal diseases: part 2. Coats' disease, Best disease, and uveitis with childhood neovascularization. J Pediatr Ophthalmol Strabismus. 2013;50(1): 11-19.

60. Saatci AO, Doruk HC, Yaman A. Intravitreal dexamethasone implant (ozurdex) in Coats' disease. Case Rep Ophthalmol. 2013;4(3): 122-128.

61. Martínez-Castillo S, Gallego-Pinazo R, Dolz-Marco R, et al. Adult Coats' disease successfully managed with the dexamethasone intravitreal implant (ozurdex ${ }^{\circledR}$ ) combined with retinal photocoagulation. Case Rep Ophthalmol. 2012;3(1):123-127.

62. Lei S, Lam WC. Efficacy and safety of dexamethasone intravitreal implant for refractory macular edema in children. Can J Ophthalmol. 2015;50(3):236-241.

63. Baillif S, Maschi C, Gastaud P, Caujolle JP. Intravitreal dexamethasone 0.7-mg implant for radiation macular edema after proton beam therapy for choroidal melanoma. Retina. 2013;33(9):1784-1790.

64. Caminal JM, Flores-Moreno I, Arias L, et al. Intravitreal dexamethasone implant for radiation maculopathy secondary to plaque brachytherapy in choroidal melanoma. Retina. 2015;35(9):1890-1897.

65. Russo A, Avitabile T, Uva M, et al. Radiation macular edema after Ru-106 plaque brachytherapy for choroidal melanoma resolved by an intravitreal dexamethasone $0.7-\mathrm{mg}$ implant. Case Rep Ophthalmol. 2012;3(1):71-76.

66. Bui KM, Chow CC, Mieler WF. Treatment of recalcitrant radiation maculopathy using intravitreal dexamethasone (Ozurdex) implant. Retin Cases Brief Rep. 2014;8(3):167-170.

67. Seibel I, Hager A, Riechardt AI, Davids AM, Böker A, Joussen AM. Antiangiogenic or corticosteroid treatment in patients with radiation maculopathy after proton beam therapy for uveal melanoma. Am J Ophthalmol. 2016;168:31-39.

68. Tarmann L, Langmann G, Mayer C, Weger M, Haas A, Wackernagel W. Ozurdex $\left({ }^{\circledR}\right)$ reduces the retinal thickness in radiation maculopathy refractory to bevacizumab. Acta Ophthalmol. 2014;92(8): 694-696.

69. Yoshida N, Ikeda Y, Notomi S, et al. Laboratory evidence of sustained chronic inflammatory reaction in retinitis pigmentosa. Ophthalmology. 2013;120(1):e5-e12.

Drug Design, Development and Therapy

\section{Publish your work in this journal}

Drug Design, Development and Therapy is an international, peerreviewed open-access journal that spans the spectrum of drug design and development through to clinical applications. Clinical outcomes, patient safety, and programs for the development and effective, safe, and sustained use of medicines are the features of the journal, which
70. Heckenlively JR, Jordan BL, Aptsiauri N. Association of antiretinal antibodies and cystoid macular edema in patients with retinitis pigmentosa. Am J Ophthalmol. 1999;127(5):565-573.

71. Cox SN, Hay E, Bird AC. Treatment of chronic macular edema with acetazolamide. Arch Ophthalmol. 1988;106(9):1190-1195.

72. García-Arumí J, Martinez V, Sararols L, Corcostegui B. Vitreoretinal surgery for cystoid macular edema associated with retinitis pigmentosa. Ophthalmology. 2003;110(6):1164-1169.

73. Yuzbasioglu E, Artunay O, Rasier R, Sengul A, Bahcecioglu H. Intravitreal bevacizumab (Avastin) injection in retinitis pigmentosa. Curr Eye Res. 2009;34(3):231-237.

74. Sallum JM, Farah ME, Saraiva VS. Treatment of cystoid macular oedema related to retinitis pigmentosa with intravitreal triamcinolone acetonide: case report. Adv Exp Med Biol. 2003;533:79-81.

75. Ozdemir H, Karacorlu M, Karacorlu S. Intravitreal triamcinolone acetonide for treatment of cystoid macular oedema in patients with retinitis pigmentosa. Acta Ophthalmol Scand. 2005;83(2):248-251.

76. Scorolli L, Morara M, Meduri A, et al. Treatment of cystoid macular edema in retinitis pigmentosa with intravitreal triamcinolone. Arch Ophthalmol. 2007;125(6):759-764.

77. Srour M, Querques G, Leveziel N, et al. Intravitreal dexamethasone implant (Ozurdex) for macular edema secondary to retinitis pigmentosa. Graefes Arch Clin Exp Ophthalmol. 2013;251(6):1501-1506.

78. Ahn SJ, Kim KE, Woo SJ, Park KH. The effect of an intravitreal dexamethasone implant for cystoid macular edema in retinitis pigmentosa: a case report and literature review. Ophthalmic Surg Lasers Imaging Retina. 2014;45(2):160-164.

79. Saatci AO, Selver OB, Seymenoglu G, Yaman A. Bilateral intravitreal dexamethasone implant for retinitis pigmentosa-related macular edema. Case Rep Ophthalmol. 2013;4(1):53-58.

80. Patil L, Lotery AJ. Coat's-like exudation in rhodopsin retinitis pigmentosa: successful treatment with an intravitreal dexamethasone implant. Eye (Lond). 2014;28(4):449-451.

81. Furino C, Boscia F, Recchimurzo N, Sborgia C, Alessio G. Intravitreal dexamethasone implant for refractory macular edema secondary to vitrectomy for macular pucker. Retina. 2014;34(8):1612-1616.

82. Taney LS, Baumal CR, Duker JS. Sustained-release dexamethasone intravitreal implant for persistent macular edema after vitrectomy for epiretinal membrane. Ophthalmic Surg Lasers Imaging Retina. 2015; 46(2):224-228

83. Merkoudis N, Granstam E. Treatment of postoperative cystoid macular oedema with dexamethasone intravitreal implant in a vitrectomized eye - a case report. Acta Ophthalmol. 2013;91(3):238-239.

84. Georgalas I, Petrou P, Papakonstantinou D, Droumouchtsis V, Tservakis I. Post-operative refractory cystoid macular edema in a vitrectomized eye treated with slow-release dexamethasone implant (Ozurdex). Cutan Ocul Toxicol. 2015;34(3):257-259.

85. Bonfiglio V, Fallico MR, Russo A, et al. Intravitreal dexamethasone implant for cystoid macular edema and inflammation after scleral buckling. Eur J Ophthalmol. 2015;25(5):e98-e100.

86. Haller JA, Bandello F, Belfort R Jr, et al. Dexamethasone intravitreal implant in patients with macular edema related to branch or central retinal vein occlusion twelve-month study results. Ophthalmology. 2011; 118(12):2453-2460.

87. Lowder CI, Belfort R Jr, Lightman S, et al. Dexamethasone intravitreal implant for noninfectious intermediate or posterior uveitis. Arch Ophthalmol. 2011;129(5):545-553.

\section{Dovepress}

has also been accepted for indexing on PubMed Central. The manuscript management system is completely online and includes a very quick and fair peer-review system, which is all easy to use. Visit http://www.dovepress.com/testimonials.php to read real quotes from published authors. 